\title{
THE IMPORTANT ROLE THAT THE BOTANICAL GARDEN OF THE NATIONAL AUTONOMOUS UNIVERSITY OF MEXICO PLAYS IN THE CONSERVATION OF MEXICAN ORCHIDS
}

\author{
AidA-TÉLLEZ VELASCO \\ Jardín Botánico del Instituto de Biología, UNAM. 3er. Circuito Exterior. Cd. Universitaria. \\ Apdo. Postal 70-614 México, D.F., C.P. 04510. México \\ atellez@ibiologia.unam.mx
}

\begin{abstract}
Resumen. El Jardín Botánico del Instituto de Biología de la Universidad Nacional Autónoma de México ubicado en la Ciudad de México, México; asentado en terrenos de origen volcánico en un matorral xerófito; tiene el propósito de mantener colecciones de plantas vivas representativas de la diversidad vegetal de México, que sirven de apoyo a la investigación, conservación, educación y Divulgación de la diversidad botánica. El Jardín posee una colección Viva de Orquídeas, tanto epífitas como terrestres, en la que se han llevado a cabo diferentes actividades. Con este trabajo se enfatiza el papel que juega el Jardín Botánico de la UNAM, en la conservación de la familia Orchidaceae de México.
\end{abstract}

Key Words: Mexico, Botanic Garden, Orchidaceae, conservation, endemic, ex situ

Mexico is located in the southernmost part of North America (14 32' 27"; $32^{\circ} 43^{\prime}$, 06" north latitude and $86^{\circ} 42^{\prime} 36^{\prime \prime} ; 118^{\circ} 22^{\prime} 00^{\prime \prime}$ west latitude). The country has an area of $1,964,375 \mathrm{~km}^{2}$ (INEGI 2006) and is divided by the Tropic of Cancer into two halves. The northern region is mostly arid, temperate, with its climate strongly influenced by North American continentality. In contrast, southern Mexico is humid and tropical due to its lower latitude and the maritime influence, and has a more rugged topography (Challenger 1998). Mexico is situated where two biogeographic regions meet, neartic and neotropical. It has complex topography as a result of its intricate geological history. These two facts are the cause of such enormous diversity in Mexico (Neyra y Durand 1998). Biological diversity in Mexico is one of the highest in the world $\left(4^{\circ}\right.$ mega diverse country) and contributes, with other 12 countries to around 60 to $70 \%$, of global diversity (Alvarado 2000) (Fig. 1).

The conservation of the biodiversity is an integral system of activities to assure the existence and natural reproduction of the populations in their natural habitat (in situ) and out of their habitat (ex situ) as Botanical Gardens do.

The Botanical Garden of the Biological Institute of National Autonomous University of Mexico
(UNAM) is situated geographically between parallel $19^{\circ} 20^{\prime} 23^{\prime \prime}$ and $19^{\circ} 13^{\prime} 45^{\prime \prime}$ north latitude and the meridians $99^{\circ} 08^{\prime} 26^{\prime \prime}$ and $99^{\circ} 14^{\prime} 37^{\prime \prime}$ east long. It is to the South of Mexico City in the area known as The Pedregal of San Angel, a volcanic site formed 2500 years ago by the Xitle volcano complex (Fig. 2).

This Botanical Garden has the intention to maintain collections of representative living plants of the vegetal diversity of Mexico. These collections, serve as support for research, conservation, education and spreading of the botanical diversity. The Garden has

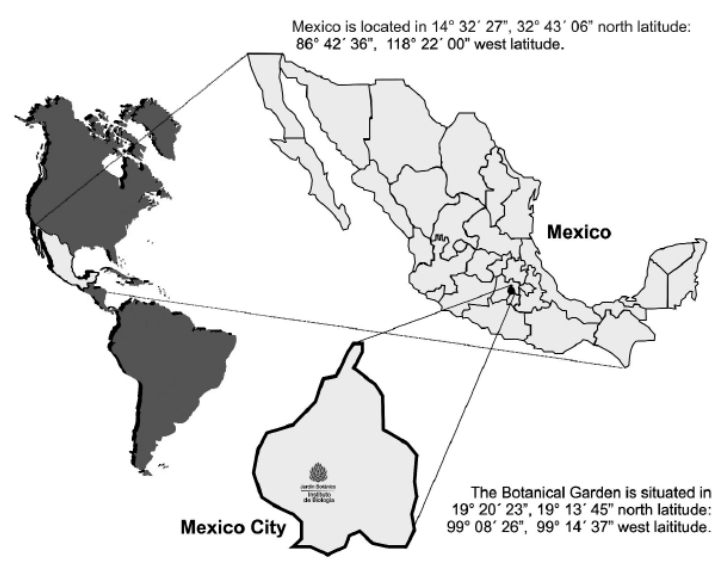

FIGURE 1. Location of Mexico in the world. Ilustration J. Saldivar. 


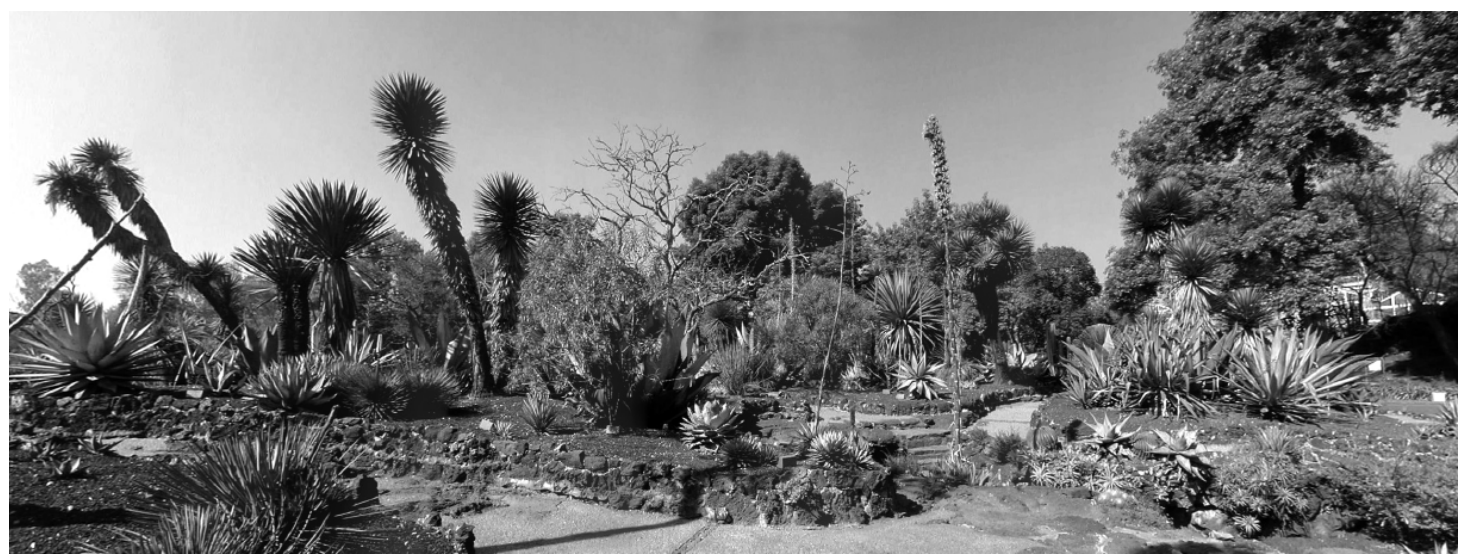

FIGURE 2. A look of the Botanical Garden, UNAM. Ilustration J. Saldivar.

plants of arid, tempered and warm-humid zones. From these last two zones, there is a living orchid collection, including epiphytes and terrestrial species (Fig. 3). This collection was started in 1960, and since then, different activities related to the conservation of biodiversity have been carried out, such as:

1. - There are 1,200 species of Mexican orchids (Hagsater et al. 2005).One of the most outstanding features of the Mexican orchid flora is the high proportion of endemic species. There are 444 endemic species o subspecies corresponding to about $40 \%$ of the total recorded flora taxonomy of this country. This feature makes the Mexican orchid flora proportionally one of the richest in endemism among non tropical mainland countries, perhaps surpassed only by Brazil (Soto 1996).

The Botanic Garden shelter and protect under culti-

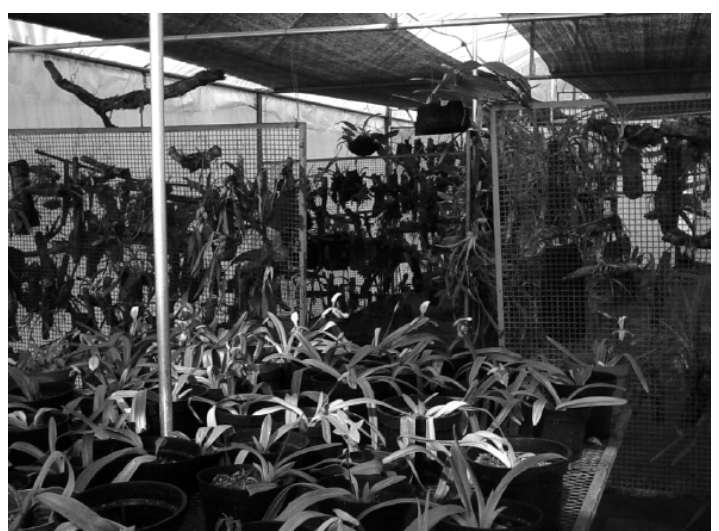

FIgURE 3. Living orchid collection of the Botanical Garden, UNAM. Ilustration A. Téllez. vation 71 genera and 176 species in 1216 specimens of Mexican species that have biological, ecological (Epidendrum magnificun), artisan (Myrmecophila tibicinis), flower industry (Cattleya aurantiaca), medicinal (Cyrtopedium puntatum), adhesive (Govenia superba), flavoring (Vanilla planifolia), comestible (Epidendrum rigidum), ornamentals (Oncidium sphacelatum), narcotic (Prosthechea radiata) importance. Each of the orchid pollination syndromes is represented with specimens: bee (Lycaste aromatica), fly (Restrepiella ophiocephala), moths (Epidendrum parkinsonianum), butterfly (Epidendrum radicans), and hummingbirds (Elleanthus capitatus). There are specimens belonging to the four subfamilies reported by Chase et al (2003): Vanilloideae (Vanilla), Cypripedioideae (Paphiopedilum ), Orchidoideae (Shiedeela) and Epidendroideae (Pleurothallis).

Mexican endemic species of orchids are safeguarded and kept, in addition to those species given the status of Probably extinct (E), In danger of extinction (P), Threatened (A), and Under special protection (PR) as stated in the Mexican Official regulations "NOM-059-ECOL-2001" SEMARNAT (2002). In this document 181 species are registered of which 72 are endemic and 109 not endemic. The Botanical Garden protects species of the category from A: [Encyclia adenocaula (endemic), Bletia urbana (endemic) and Chysis bractensis] and in the category of PR: [(Vanilla planifolia (endemic), Prosthechea vitellina, Euchile citrina (endemic) and Laelia speciosa (endemic)] (Fig. 4). 
The objective of this ex-situ conservation is to assure the protection the species, while mantening the variability of these. The Garden has responsibility on these plants like deposit takers perhaps of the only germoplasma surplus of threatened species. For that reason, they are subject of special attention regarding their maintenance, horticultural and curatorial activities and propagation.

2. - Accomplishment of diverse studies of in vitro propagation, of some species with conservation problems, including the formation of somatic embryos from apex of protocorms (Euchile maria, Trichocentrum carthagenenese); multiple sprouting of knots, obtaining direct and indirect organogenesis from leaves (Vanilla planifolia); regeneration of plants from callus, by seed (Bletia urbana y Stanhopea tigrina); by leave section (Laelia speciosa), symbiotic and asymbiotic germination (Bletia campanulata, Dichromanthus aurantiacus y Dichromanthus cinnabarinus).

With these propagation methodologies that do not damage wild populations, parts or complete seedlings are obtained that represent a heritage or bank of germoplasm in vitro and ex vitro as well as ex situ. The reintroduction of some terrestrial orchids to its habitat (Bletia urbana and Dichromanthus aurantiacus), is another activity directed to re-establish not only the vegetal structure, but also the operation of the ecosystems (Fig. 5).

3. - Observation and in situ monitoring of endemic species or species with conservation problems, in protected natural areas like "Ecological Reserve of the Pedregal de San Angel" located within the grounds of the UNAM, for studies of distribution, ecology and phenology of terrestrial orchids, registering one endemic species, (Bletia urbana) (Tellez 2002). The Botanical Garden has in shelter $86 \%$ of the registered terrestrial species for the Reserve (Fig. 6).

In the Reserve of the Biosphere, Barranca de Metztitlán, in Hidalgo, Mexico, species as Laelia gouldiana, endemic of the area and Laelia speciosa, endemic of Mexico, among others species, are being monitored (Fig. 7).

4. - During recent years the Mexican natural habitat has been transformed by heavy logging, agriculture, cattle raising, chemical pollution, wood fires and

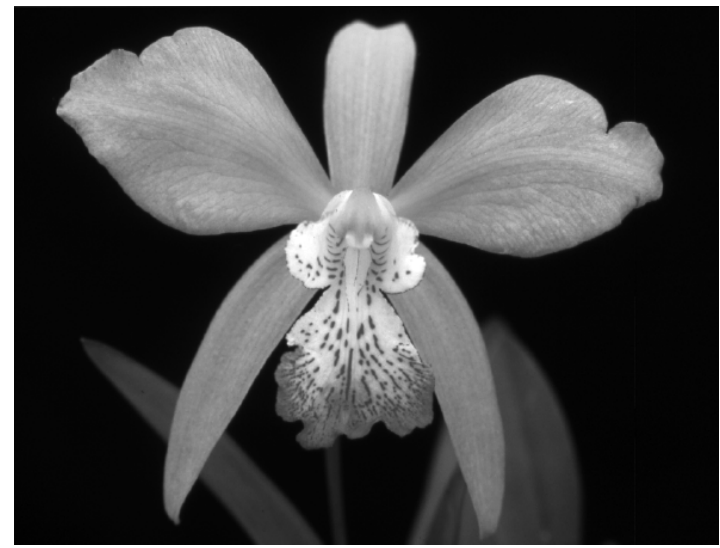

Figure 4. Laelia speciosa, endemic species of Mexico and subject to special protection. Ilustration A. Téllez.

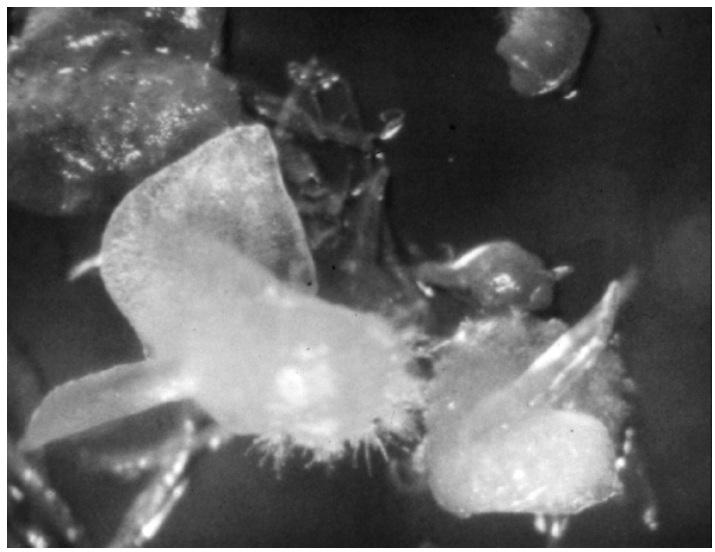

FIGURE 5. In vitro propagation of Euchile citrina. Ilustration A. Téllez.

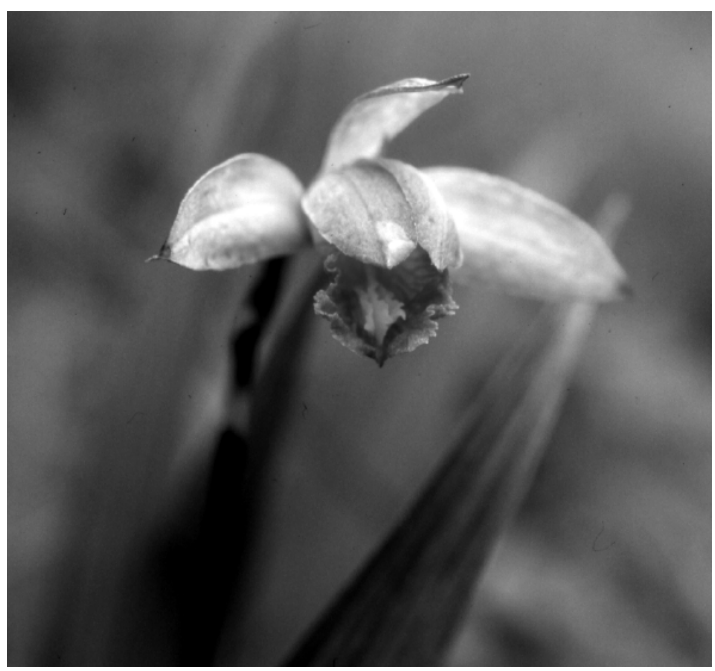

Figure 6. Bletia urbana endemic species of Mexico and under special protection. Ilustration A. Téllez. 


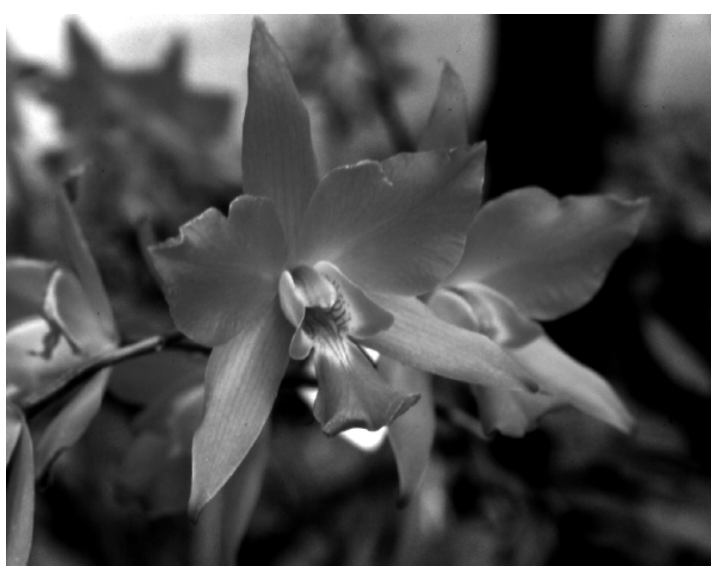

FigURE 7. Laelia gouldiana, extinct and endemic species of Barranca de Metztitlan, Hidalgo.Mexico. Ilustration A. Téllez.

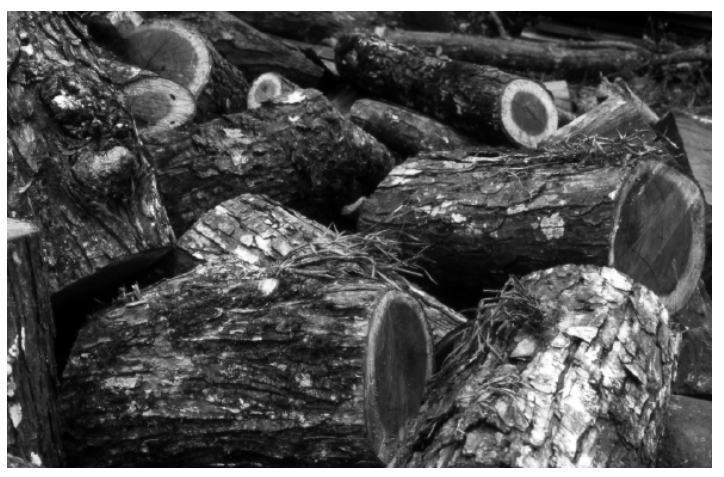

FIGURE 8. Rescue of orchids in Santa Marta, Veracruz, Mexico. Ilustration A. Téllez.

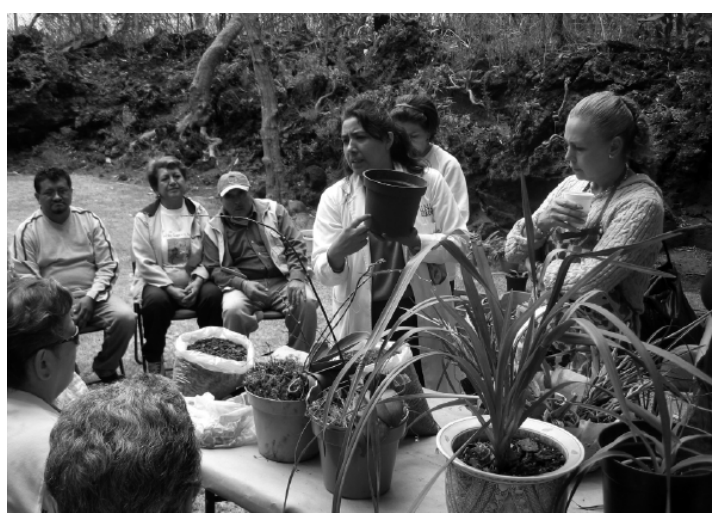

FIGURE 9. Workshop of orchid growing and propagation in Mexico City. Ilustration A. Téllez.

urban expansion - all these in addition to the extraction of species of commercial value. For this reason, the Botanical Garden have to rescue plants in zones that have been altered by urbanism, as is the case of
Distrito Federal (inside UNAM campus), in which terrestrial orchids have been rescued (among which are Sarcoglottis schaffneri, Dichromanthus aurantiacus, Habenaria novemfida) and in Xalapa, Veracruz, Mexico, where Bletias are being rescued in places where highways are being expanded or rocks are being mined (Fig. 8).

5. - The collections of the botanical Garden and their biodiversity are means so that the people form an idea of the problematic and importance of conservation. An educative relation with its users must exist; because the collections by themselves do not work like tools of environmental education if they do not count on information that allows to interpret them; as labels, calendars, guided visits, preparation of materials like news bulletins, guides of routes, exhibitions, conferences, talks, courses and workshops.

Activities like workshops, courses and exhibitions that support the environmental education of people, from children to adults, having the objective to spread knowledge and to create environmental awareness. As an example of workshops there are those directed to cultivators, plant dealers, and public in general on the cultivation and propagation of orchids and one directed for children named "An orchid called Vanilla" (Fig. 9).

Finally, this work emphasises the importance and the role that the Botanic Gardens of the UNAM plays, in the conservation of the Orchidaceae family of Mexico.

ACKNOWLEDGMENTS.To Jorge Saldivar.for the images in fig. 1 and 2.To Armando Roa for helping in the translation..

\section{Literature Cited}

Alvarado, Z. A. 2000. Campamento biofilia. La biodiversidad. SOMEDICIT-SEMARNAP, México, D.F. 91 p.

Challenger, A. 1998. Utilización y conservación de los ecosistemas terrestres de México, Pasado, presente y futuro. CONABIO.México, D.F.847 p.

Chase M.W., K.M. Cameron, R.L. Barrett y J.V. Freudenstein. 2003. DNA data and Orchidaceae systematics: A new phylogenetic classification. Pp. 9-89 in K.W. Dixon, S.P. Kell, R.L. Barrett \& P.J.Cribb (eds.). Orchid conservation. Natural History Publications (Borneo), Kota Kinabalu Sabah. 
Hagsater, E., M. Soto Arenas, G.A. Salazar Chavéz, R. Jiménez Machorro, M. A. López Rosales \& R.L. Dressler. 2005. Las orquídeas de México. Instituto Chinoín, México, 304 p.

INEGI(2006. http://mapserver.inegi.gob.mx/geografia/ espanol/datosgeogra/extterri/frontera.cfm?c $=154$

Neyra G. \& L. Durand S. 1998. Biodiversidad. Pp. 61-102 in: Conabio (comp.) La diversidad biológica de México. Estudio de país. CONABIO. México, D.F.
Rzedowski, J. 1978. Vegetacón de México. LIMUSA. México, D.F.432 p.

SEMARNAT. 2002. Norma Oficial Mexicana. Proy. NOM.059-ECOL-2001. Diario Oficial de la Federación, marzo. México, D.F.

Soto A.M. 1996. Mexico. Pp. 53-58 in: E. Hágsater\& V. Dumont (eds.). Orchids. IUCN. Cambridge.

Tellez-Velasco, A. 2002. The Pedregal of San Angel and its orchids. Orchid Rev. 110 (1242): 25-29.

Aída Téllez Velasco studied Biology at the National Autonomous University of Mexico (UNAM) and then a Master in Science in the same University. She is currently the curator of the living orchid collection at the Botanical Garden in the UNAM. She has worked in various fields related to orchids carrying out curatorial and horticultural activities and in vitro research as well as the management of greenhouses. She also gives workshops and courses and has published several papers in books and journals. She has been Chairman of the Board and Editor of the Journal of the Mexican Association of Botanical Gardens. 